\title{
Primary Pineal Glioblastoma: A Case Report
}

\author{
Primer Pineal Glioblastom: Bir Olgu Sunumu
}

\author{
Onur OZGURAL ${ }^{1}$, Gokmen KAHILOGULLARI ${ }^{1}$, Melih BOZKURT ${ }^{1}$, Aylin OKCU HEPER ${ }^{2}$, Ali SAVAS ${ }^{1}$ \\ ${ }_{1}^{1}$ Ankara University, Faculty of Medicine, Department of Neurosurgery, Ankara, Turkey \\ ${ }^{2}$ Ankara University, Faculty of Medicine, Department of Pathology, Ankara, Turkey
}

Corresponding Author: Gokmen KAHILOGULLARI / E-mail: gokmenkahil@hotmail.com

\begin{abstract}
Glioblastoma is very rare in the pineal region. We report a case of glioblastoma in this region. This is the 18th case of primary glioblastoma in the pineal region and the second case that survived over two years according the literature. A 60-year-old man admitted with headache and ataxia that continued for the last 3 months. Physical examination was normal. Neurological examination revealed ataxia. There was no motor or sensory deficit. Computer tomography showed triventricular hydrocephalus and isodense rounded mass in the pineal region. Magnetic resonance images revealed a regular-edged heterogeneous contrast-enhanced tumor in pineal region. A ventriculoperitoneal shunt was inserted for hydrocephalus. After surgery, the ataxia and hydrocephalus were improved. Ten days later, serial stereotactic biopsies were performed. Histopathological specimens revealed glioblastoma. The patient was recommended to undergo radiotherapy and chemotherapy. The patient is still surviving without deficit two years after biopsy and shunt operation.
\end{abstract}

KEYWORDS: Glioblastoma, Pineal region, Biopsy

öz

Glioblastom pineal bölgede oldukça nadir görülür. Çalışmamızda, bu bölgede görülen bir glioblastom olgusu sunuldu. Bu olgu literatürde sunulan pineal bölgenin 18. primer glioblastom tanılı olgusu ve iki yıl üzerinde yaşayan ikinci olgusudur. 60 yaşında erkek hasta 3 aydır süren baş ağrısı ve ataksi şikâyetleriyle başvurdu. Fizik muayenesi normal idi. Nörolojik muayenesinde ataksi tespit edildi. Motor ve duyusal defisit tespit edilmedi. Bilgisayarlı tomografide triventriküler hidrosefali ve pineal bölgede yuvarlak izodens kitle görüldü. Manyetik rezonans görüntülemede pineal bölgede düzgün sınırlı heterojen kontrastlanma gösteren tümör görüldü. Hidrosefali için ventriküloperitoneal şant operasyonu yapıldı. Operasyon sonrası ataksi şikâyetleri ve hidrosefalisi düzeldi. On gün sonra kitleden seri stereotaktik biyopsiler alındı. Histopatolojik değerlendirme sonucu glioblastom olarak geldi. Hastaya kemoterapi ve radyoterapi uygulandı. Hasta biyopsi ve şant operasyonu sonrası 2 yılı aşkın süredir yaşamaktadır.

ANAHTAR SÖZCÜKLER: Glioblastom, Pineal bölge, Biyopsi

\section{INTRODUCTION}

Tumors of the pineal region include germ cell tumors, parenchymal tumors and supporting tissue tumors like gliomas. Germ cell tumors are the most common tumor type of the pineal region $(1,16)$. The second most frequent type is glial tumor but is mostly low grade glioma and the third is parenchymal tumors such as pineocytoma or pineoblastoma (1). Glioblastoma (GBM) is rare in this region $(6,12,16)$. We report a rare case of GBM in the pineal region. This is the $18^{\text {th }}$ case of primary glioblastoma in the pineal region and the second case that survived over two years according the literature (12).

\section{CASE REPORT}

A 60-year-old man was admitted to hospital with headache and ataxia that had continued for the last 3 months. Physical examination was normal. Neurological examination revealed ataxia. There was no motor or sensory deficit. Computerized tomography (CT) showed triventricular hydrocephalus and an isodense rounded mass in pineal region. Magnetic resonance images revealed a regular-edged heterogeneous contrast-enhanced tumor in the pineal region (Figure 1A, B). First of all, a ventriculoperitoneal shunt was inserted to the patient for hydrocephalus (Figure 1C). After surgery, the ataxia and hydrocephalus were improved. Ten days later, serial stereotactic biopsies were performed (Figure 1C). The paraffin embedded and H\&E stained sections of stereotactic biopsies revealed a tumor composed of pleomorphic, atypical glial cells (Figure 2A, B). Mitotic figures, necrosis and vascular endothelial proliferation were also noted. Immunohistochemical analysis demonstrated GFAP expression (Figure 2C) with high (15\%) Ki67 proliferation index. More than half of the tumor cells were p53 positive. The tumor cells were negative with pan-ck. Pathology result was glioblastoma. The patient was recommended to undergo radiotherapy (RT) and chemotherapy (CHT). The patient was treated with median $60 \mathrm{~Gy}$ in 2 Gy single fractions RT, and for the $\mathrm{CHT}$ regime, $75 \mathrm{mg} / \mathrm{m}^{2} /$ per day temozolamide was used during RT. The patient is still surviving two years after the biopsy and shunt operation, without deficit. 

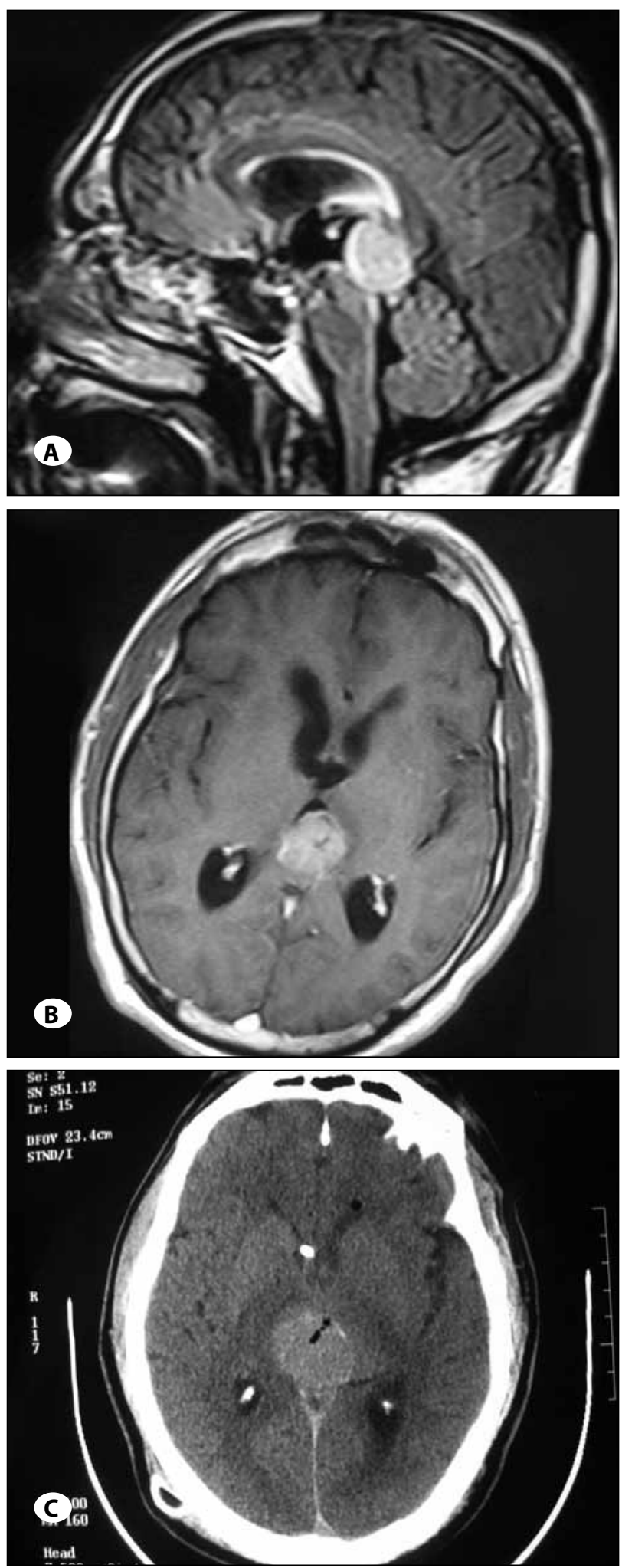

Figure 1: A) Preoperative magnetic resonance imaging shows heterogeneous mass in the pineal region (sagittal section). B) Preoperative magnetic resonance imaging shows heterogeneous mass in the pineal region (axial section). C) Computerized tomography shows tumor of the pineal region after ventriculoperitoneal shunt and stereotactic biopsy.
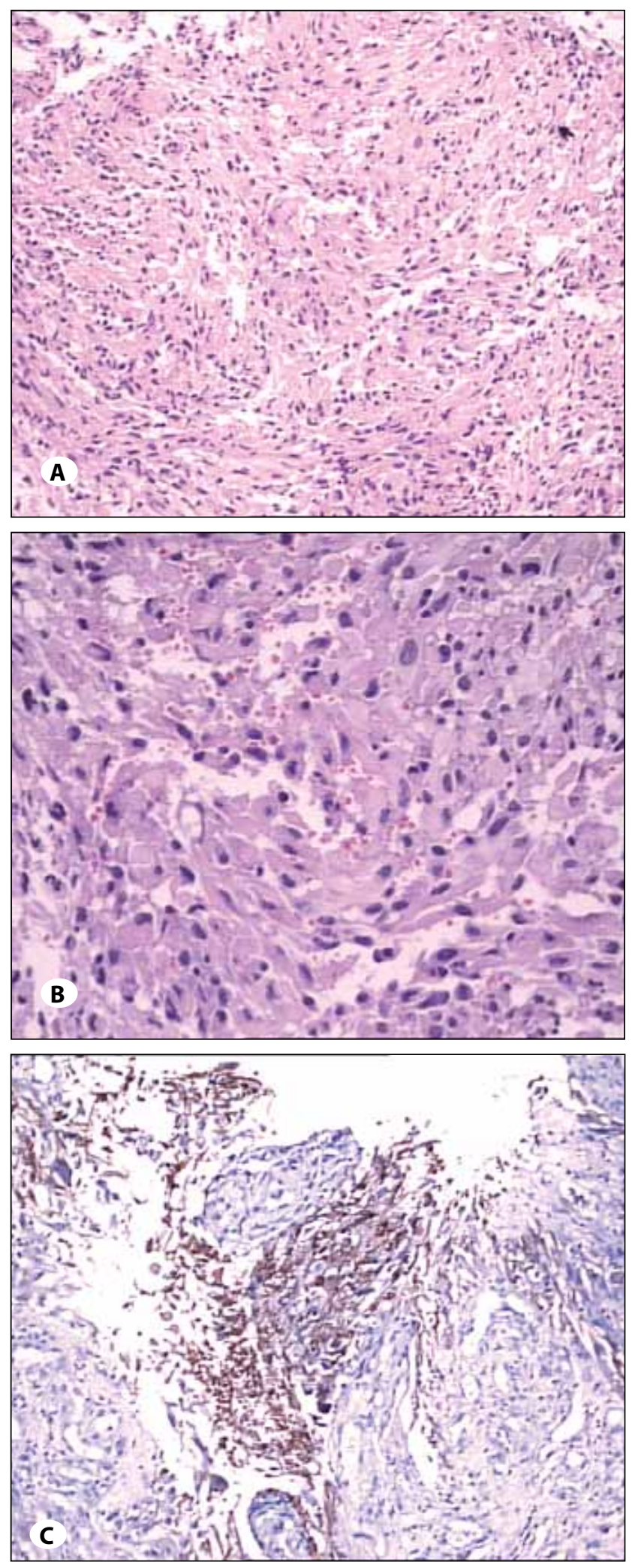

Figure 2: A) Tumor composed of pleomorphic atypical glial cells, H\&Ex200. B) The closer view of tumor cells, H\&Ex400. C) Immunohistochemical assessment: The cytoplasmic GFAP expression of the tumor cells. The vascular endothelial proliferation was also present. GFAPx200. 


\section{DISCUSSION}

The pineal region is framed superiorly by the corpus callosum, anteriorly by third ventricle, laterally thalamus and cerebral hemisphere, and posteriorly the habenularum (3). Tumors of this region are rare and make up less than $1 \%$ of all intracranial tumors $(1,6)$. Tumors can be derived from the pineal gland itself, germ cells as in germinomas, and teratomas and supporting tissue as in gliomas. The tumors of this region may both stem from pineal gland and also the posterior part of the third ventricle or the quadrigeminal cistern (9). These tumors are generally irregular and compress neighboring structures like aqueductus sylvii and frequently cause hydrocephalus (3). MRI reveals association with neighbor tissue and vascularity of tumor. Although glioblastoma is the most primary malign tumor of brain, it is seen rarely in the pineal region. Only a few cases of GBM of the pineal region have been reported $(4,5,6,8,10,14,15)$.

The germ cell tumors and especially germinoma and teratoma are the most common tumors of pineal region. It is predominant in males. It occurs generally in the first two decades $(6,16,18)$. They may appear hyperdense on $C T$, with a strong contrast enhancement. In CT, low grade astrocytomas are seen iso- hypodense and with moderate contrast enhancement. MRI may show iso-hypointense on T1weighted images and hyperintense on T2-weighted images. MRI may show an isodense lesion. Parenchymal tumors of pineal region are pineocytoma, pineoblastoma, cysts etc. These tumors are often seen in older ages and equally in males and females. Pineoblastoma is seen with heterogenous contrast enhancement and generally invades adjacent tissue. MRI may show an iso or hypointense lesion on T1-weighted images and hyperintense on T2-weighted images. Other tumors arising from the glial components of the pineal gland include ganglioneuroma, ganglioglioma, meningioma, and gliomas, more frequently low-grade astrocytomas $(6,18)$.

Despite all available treatment protocols, GBM is a progressive malignant tumor with aggressive course and short survival. The mean survival in patients undergoing radiotherapy and chemotherapy after surgical resection in pineal region GBMs was shown to be 7 months $(12,15)$. Longer survival durations are also present in the literature regarding pineal GBMs. One of the cases survived 27 months was operated for hydrocephalus and a shunt was inserted. The second case had radiotherapy and chemotherapy after resection and survived 18 months $(6,12)$. These cases were both girls 5 and 12 years old respectively. The presented case underwent stereotaxic surgery and RT/CHT as the treatment protocol and survived more than 2 years. This was the first adult GBM reaching a survival of more than 2 years. It is known that the pineal gland is a unique structure where the blood-brain-barrier is not present $(2,7)$ and this knowledge may be the reason why $\mathrm{CHT}$ agents could be more effective in this region $(11,13,17)$.

Despite its rarity, GBM should be considered if there is a tumor in pineal region. We suggest that stereotaxic surgery may be an effective alternative considering the difficulty of accessing this region and the aggressive nature of the tumor. This technique enables pathologic diagnosis without wide resection and with a minimal complication rate. We also suggest that RT/CT following stereotaxic biopsy may significantly contribute to the survival of patients with GBM.

\section{REFERENCES}

1. Bailey S, Skinner R, Lucraft HH, Perry RH, Todd N, Pearson ADJ: Pineal tumours in the North of England 1968-93. Arch Dis Child 75:181-185, 1996

2. Ballabh P, Braun A, Nedergaard M: The blood-brain barrier: An overview: Structure, regulation, and clinical implications. Neurobiol Dis 16:1-13, 2004

3. Caldas, JG, Doyon D, Lederman H, Carlier R: Magnetic resonance study of the pineal region. Normal pineal gland and simple cysts. Arq Neuropsiquiatr 56:237-244,1998 (Article in Portuguese)

4. Cho BK, Wang KC, Nam DH, Kim DG, Jung HW, Kim HJ, Han $\mathrm{DH}$, Choi KS: Pineal tumors: Experience with 48 cases over 10 years. Childs Nerv Syst 14:53-58, 1998

5. De Girolami U, Schmidek H: Clinicopathological study of 53 tumors of the pineal region. J Neurosurg 39:455-462, 1973

6. Edwards MSB, Hudgins RJ, Wilson CB, Levin VA, Wara WM: Pineal region tumors in children. J Neurosurg 68:689-697, 1988

7. Ermisch A, Rühle HJ, Landgraf R, Hess J: Blood-brain barrier and peptides. J Cereb Blood Flow Metab 5:350-357, 1985

8. Frank F, Gaist G, Piazza G, Ricci RF, Sturiale C, Galassi E: Stereotaxic biopsy and radioactive implantation for interstitial therapy of tumors of the pineal region. Surg Neurol 23:275280, 1985

9. Gasparetto EL, Warszawiak D, Adam GP, Bleggi-Torres LF, de Carvalho Neto A: Glioblastome multiforme of the pineal region: A case report. Arq Neuropsiquiatr 61:468-472, 2003

10. Kalyanaraman UP: Primary glioblastoma of the pineal gland. Arch Neurol 36:717-718, 1979

11. Matsutani M: Pineal germ cell tumors. Prog Neurol Surg 23: 76-85, 2009

12. Moon KS, Jung S, Jung TY, Kim IY, Lee MC, Lee KH: Primary glioblastoma in the pineal region: A case report and review of the literature. Journal of Medical Case Reports 2: 288, 2008

13. Nakamura H, Makino K, Kochi M, Nakazato Y, Kuratsu J: Successful treatment of neoadjuvant therapy for papillary tumor of the pineal region. Brain Tumor Pathol 26:73-77, 2009

14. Norbut AM, Mendelow H: Primary glioblastoma multiforme of the pineal region with leptomeningeal metastases: A case report. Cancer 47:592-596, 1981

15. Pople IK, Arango JC, Scaravilli F: Intrinsic malignant glioma of the pineal gland. Childs Nerv Syst 9:422-424, 1993

16. Prahlow JA, Challa VR: Neoplasms of the pineal region. South Med J 89:1081-1087, 1996

17. Ueba T, Yamashita K, Fujisawa I, Nakao S, Ooyama K, Yorihuji T, Kato SF, Seto S, Kageyama N: Long-term follow-up of 5 patients with intracranial germinoma initially treated by chemotherapy alone. Acta Neurochir (Wien) 149:897-902, 2007

18. Vaquero J, Ramiro J, Martinez R, Bravo G: Neurosurgical experience with tumours of the pineal region at Clinica Puerta de Hierro. Acta Neurochir (Wien) 116:23-32, 1992 